\title{
Procesy integracyjne w Europie a implikacje oświatowe Europejskie agendy oświatowe
}

Procesy integracyjne realizowane w ramach Unii Europejskiej uległy w ostatnim czasie osłabieniu z powodu kryzysu wewnętrznego tej ponadnarodowej organizacji, zmierzającej do utworzenia kulturowo homogenicznego „super państwa”. Idea takiej integracji o modelu liberalnym światopoglądowo i aksjologicznie ${ }^{2}$ napotyka coraz silniejszy opór poszczególnych wyznań religijnych i katolickich kościołów lokalnych (np. w Hiszpanii, Włoszech, Meksyku, Polsce). Nasiliły go znacznie poważniejsze antagonizmy wewnętrzne, np. odrzucenie przez Holandię i Francję unijnej konstytucji, krytyka T. Blaira skierowana przeciw unijnemu budżetowi na lata 2007-2013³. W europejskich środowiskach liberalnych i socjalistycznych pisze się jednak o konieczności jej kontynuowania (m.in. premier Holandii Jan Peter Balkenende, kanclerz Niemiec Gerhard Schroeder), dalszej realizacji zmian funkcjonalnych, opracowania „nowej wizji” zmodyfikowanego projektu Europy (Martin Schulz z SPD - frakcja socjalistyczna Parlamentu Europejskiego, prezydent Czech Vaclav Klaus ${ }^{4}$ ) i tylko

\footnotetext{
* Dr Ryszard Małachowski jest pracownikiem naukowym Uniwersytetu Zielonogórskiego.

${ }^{1}$ Odrzucono zatem propozycję dotyczącą utworzenia narodowych grup poszczególnych krajów w Parlamencie Europejskim.

${ }^{2}$ Niedopuszczenie do wymienienia imienia Boga w preambule konstytucji Unii Europejskiej, dyskryminowanie chrześcijan (np. filozofa i polityka, prof. Rocco Buttiglione), uznanie za równoprawne $-\mathrm{z}$ heteroseksualnymi - przejawy zachowań homoseksualnych, tzw. pro-active action i odrzucenie tradycyjnego modelu rodziny, aktywna pomoc medycyny w samobójstwie, proces dekonstrukcji kulturowo-cywilizacyjnej, islamizacja.

${ }^{3}$ Autorem tego budżetu był niemiecki deputowany do Parlamentu Europejskiego Reimer Boege.

${ }^{4}$ Proponując w dziedzinie politycznej tworzenie liberalnej demokracji, żądał on odejścia od narzucanego jego zdaniem modelu ,państwa Europa” i „europejskiego” obywatelstwa na rzecz unii opartej na członkostwie suwerennych państw. Nadto, w 2005 rok tylko $21 \%$ obywateli czeskich popierało konsty-
} 
chwilowego opóźnienia ratyfikacji, być może ateistycznej eurokonstytucji. W tej sytuacji ponowny namysł nad możliwymi rozwiązaniami, dotyczącymi potencjalnych form współistnienia państw europejskich, wymaga bardziej stanowczego wzięcia pod uwagę znaczenia historyczno-aksjologicznej genezy kulturowego organizowania się „Starego kontynentu”.

Badając dziedzinę integracji europejskiej, eksponuje się jej bardzo wczesne, historyczne ślady, np. traktat De recuperatione terra sanctae Pierre'a Dubois z 1305/1307 roku, Monarchię Dantego, czy też pomysł I. Kanta sugerujący skonfederowaną wizję Europy, oraz idee wieku XVII-XVIII: filozoficzno-estetyczne w sztuce (W. Hugo), filozofie materializmu indywidualistycznego (liberalizm, naturalizm, J. J. Rousseau), materializmu kolektywistycznego (monizm F. Engelsa, K. Marksa). Kolejne symptomy integracji ujawniające się w wieku XIX były coraz wyraźniejsze w 1. połowie XX wieku, tj. w polityce lat 30 . i dalszych minionego stulecia. To tworzenie się ,nowego ładu" społecznego w Europie nie było zjawiskiem spontanicznym, lecz planowym procesem: ideologicznym, militarnym, ekonomicznym i politycznym działaniem, o coraz bardziej sprecyzowanym celu ideowo-organizacyjnym.

Jeśli chodzi o aspekt edukacyjny, stanowiący główną problematykę podjętych rozważań, tendencję do częściowej synchronizacji wybranych elementów praktyki oświatowej (zwłaszcza zawodowej) w systemach szkolnych Europy Zachodniej, poprzedziła najpierw integracja $\mathrm{w}$ zakresie polityki gospodarczej, kontynuowanej do chwili obecnej ${ }^{5}$. Już po II wojnie światowej reaktywowano ideę europejskich „Stanów Zjednoczonych [...]”, przypisywaną W. Churchillowi przedstawiającemu ją w roku 1946 i 1948 na forum międzynarodowym ${ }^{6}$. Następnie wraz z upływem czasu

tucję UE, ale 73\% nie życzyło sobie ratyfikacji tego dokumentu. Jak podawał czeski dziennik „Mlada Fronta Dnes", także 21\% Czechów nie popiera konstytucji UE, a 73\% nie życzy sobie kontynuowania ustawicznej propagandy na rzecz tego dokumentu.

${ }^{5}$ Dziewulak, Polityka oświatowa wspólnoty europejskiej, wyd. 2, Warszawa 1995, s. 110; R. Coudenhove-Kalergi, Naród europejski, Toruń 1997, s. 51; F. Emmert, M. Morawiecki, Prawo europejskie, Warszawa-Wrocław 2000, s. 11.

${ }^{6}$ Autorem tej idei był Victor Hugo, który ,proponował w 1849 roku utworzenie »Stanów Zjednoczonych Europy«. [...]”, w: F. Emmert, M. Morawiecki, dz. cyt., s. 11. Okazało się jednak, że; „Głównym źródłem oporu wobec globalizacji i wielkiego projektu Stanów Zjednoczonych Europy stało się kilka wielkich religii. Szczególnie silnie przeciwstawiają się temu wojujący islam i neokonfucjanizm, głoszący wartości azjatyckie, choć nie należy gubić z pola widzenia alternatywnej wizji »ładu społecznego« proponowanej przez katolicyzm”, zob. L.W. Zyblikiewicz, Narody i religie, w: E. Cziomer, L.W. Zyblikiewicz, Zarys wspótczesnych stosunków międzynarodowych, Warszawa-Kraków 2000, s. 62. Koncepcję chrześcijańską potwierdził papież Jan Paweł II w idei globalnej solidarności, wskazując na nią z powodu tych, którzy globalizm postrzegają jako formę neokolonializmu, zob. A. Tokárowá, Globalizacja - szanse, zagrożenia i konsekwencje społeczne, w: Profesje społeczne w Europie, Z problemów kształcenia i działania, red. E. Marynowicz-Hetka, A. Wagner, J. Piekarski, Katowice 2001, s. 63. Po II wojnie światowej zjednoczeniową koncepcje chrześcijańską reprezentowali: Robert Schuman, Konrad Adenauer, Alcide de Gasperi, Paul Henry Spak, w: J. Wahl, Robert Schuman Ojciec Europy, Gliwice, [b.m., b.r.]; G. Venheeswijck, Wspólnota Jeana Monneta, w: Chrześcijaństwo, a integracja europejska, red. J. Sveeney, J. van Gerwen, Kraków 1997, s. 66. Za drugą ateistyczną koncepcją globalizmu opowiadali się m.in.: M. Horkheimer, T. Adorno, H. Marcuse, R. Garaudy, Z. Bauman, L. Kołakowski, J. Habermas, I. Berlin, 
forsowany - opozycyjny wobec katolickiego - ateistyczny kierunek integracji uzyskał przewagę polityczną. Tymczasem pośród wielości inicjatyw Kościół katolicki ustawicznie proponował i nadal popiera koncepcję powszechnej solidarności państw i dążenie do wzajemnego, solidarnego rozwoju kulturowego i ekonomicznego Europy - jednakże Europy o kulturze chrześcijańskiej.

Jedną z pierwszych zinstytucjonalizowanych organizacji dążących do integracji, zwanej federalizacją naszego kontynentu, była Unia Europejskich Federalistów założona w Paryżu w 1946 roku. Występowała ona z propagandowym programem condorsetowskiej neutralności politycznej, religijnej, tolerancji wobec wielokulturowości, mniejszości narodowych, grup etnicznych wraz z ich tradycjami. Realizację idei globalnej tolerancji, a szczególnie zjednoczenia Europy w federację, UEF traktuje jako propagandowy warunek uniknięcia globalnego konfliktu militarnego, zachowania ,pokoju i dobrobytu w Europie" tatów integracyjnych państw członkowskich, celem współczesnej Europy winna być solidarność między narodami, pokój i zintegrowana, jednolita organizacyjnie baza rozwoju gospodarczego. Twierdzi się, że „Europę taką można budować wyłącznie przez konkretne działania tworzące najpierw solidarność faktyczną, oraz przez ustanowienie wspólnych podstaw rozwoju gospodarczego"s.

W rozważaniach o integracji Europy newralgicznym ,punktem wyjścia są zagrożenia bezpieczeństwa, a nawet tożsamości, dość często pojawiające się w dziejach, obecnie zaś wynikające $\mathrm{z}$ globalizacji przedstawianej jako $\mathrm{w}$ istocie pierwsza prawdziwa rewolucja". Mimo negatywnych historycznie skojarzeń związanych z terminem „rewolucja”, próbę integracji ekonomicznej podjęła w 1947 roku Holandia, Luksemburg i Belgia. Zmierzały one do utworzenia Unii Celnej, a w wyniku transformacji tej pierwszej w 1958 roku - do „Unii Ekonomicznej Beneluksu”10, według C. Mika - „Unii Gospodarczej Beneluksu”"1. Próby takie podejmowano szczególnie w zakresie gospodarczym, ekonomicznym (ekonomia liberalna), społeczno-politycznym (eliminacja wszelkich form „dyskryminacji” i „ksenofobii”), militarnym pod

K. Popper, R. Aron, F. Von Hayek, M. Novak, J. Tischner, J. Derida, H. Silvermann, i in. Reprezentowane przez nich koncepcje filozoficzne kontestowały wiele zagadnień natury religijnej i socjologicznej, taktycznie uznając, że: „narody i grupy etniczne [...] należą do najważniejszych uczestników współczesnych stosunków międzynarodowych", zob. L.W. Zyblikiewicz, Narody i.., w: E. Cziomer, L.W. Zyblikiewicz, dz. cyt., s. 52. Stały się one jednak przedmiotem dążeń tzw. inżynierii społecznej, gospodarczej oraz federacyjnej polityki instytucji ponadnarodowych i rządów najbogatszych państw świata. Polskim inicjatorem unifikacji europejskiej był Józef Retinger związany z grupą Bilderberg, w: G. Witkowski, J. Retinger. Polski inicjator integracji europejskiej, Warszawa 2000, s. 127.

${ }^{7}$ E. Carr-de Avelon, By Europa miała duszę, Biuletyn Informacyjny, Fundacja Krzyżowa dla Porozumienia europejskiego 2000, nr 4, s. 29.

${ }^{8}$ C. Mik, Europejskie prawo wspólnotowe, Warszawa 2000, t. 1, s. 85.

${ }^{9}$ L.W. Zyblikiewicz, Narody i..., w: E. Cziomer, L.W. Zyblikiewicz, dz. cyt., s. 61.

${ }^{10}$ K. Michałowska-Gorywoda, Geneza, cele i członkostwo Unii Europejskiej, w: Unia Europejska, red. L. Ciamaga, K. Michałowska-Gorywoda, L. Oręziak, E. Teichmann, Warszawa 2000, s. 12.

${ }^{11}$ C. Mik, dz. cyt., s. 2. 
przywództwem USA (utworzenie NATO 4 kwietnia 1949 roku) i oświatowym (utworzenie agend oświatowych ONZ). Dla międzynarodowej internalizacji założonych celów zorganizowano integracyjne struktury instytucjonalne, m.in. EWG i ONZ (po rozwiązaniu Ligi Narodów) ${ }^{12}$, sformułowano podstawy prawne (traktaty, umowy stowarzyszeniowe, ustawy), programowe i działania propagandowe (projekty). Pomimo to obserwuje się niechęć części społeczeństw Unii Europejskiej i krajów z nią niezrzeszonych do jej poszerzania, zgodnie z paternalistycznym postulatem głoszącym przekonanie, iż: „Organizacje ponadnarodowe, jak np. UE, mają być pomocnicze w stosunku do poszczególnych krajów, przejmując odpowiedzialność za te sprawy, których jednostkowe państwo w okresie globalizacji nie może rozwiązać samodzielnie"13. Wyżej wymienione stwierdzenia sugerują pośrednio, iż końcowym efektem dążeń integracyjnych ma być ostateczna unifikacja struktur ekonomiczno-państwowych i militarnych w Europie XXI wieku. Próby przyjęcia konstytucji europejskiej, mimo ewidentnego kryzysu, głównie gospodarczego, budżetowego i moralnego, powstającego wokół tego procesu, zdają się tendencję unifikacyjną zdecydowanie potwierdzać.

W kolejnym etapie unifikacji, po kilku latach od wystapienia W. Churchilla (w 1946 i 1948 r.), opracowano podstawowy akt prawny, tzn. Traktat paryski z 18 kwietnia 1951 roku. W przyszłości wzorować się miał na nim traktat o UE (Traktat z Maastricht). Na mocy tegoż Traktatu paryskiego doszło do powstania Europejskiej Wspólnoty Węgla i Stali - EWWiS. Wymienioną „Wspólnotę” założyły 18 kwietnia 1951 roku: RFN, Francja, Belgia, Holandia, Luksemburg, Włochy, m.in. z inicjatywy ministra spraw zagranicznych Francji R. Schumanna. W niedługim czasie, bo 25 marca 1957 roku, po podpisaniu umowy stowarzyszeniowej, ewoluowała ona w kierunku założenia Europejskiej Wspólnoty Gospodarczej (EWG). Równolegle w 1957 roku utworzono Europejską Wspólnotę Energii Atomowej. Traktat założycielski EWEA wszedł w życie 1 stycznia 1958 roku na czas nieograniczony.

W dniu 25 marca 1957 roku, tj. w dniu ratyfikowania Traktatu rzymskiego, założenie EWG i EWEA stało się faktem o znaczeniu gospodarczo-ekonomicznym, politycznym i militarnym. W 1961 roku inicjatorem pierwszego inauguracyjnego posiedzenia przedstawicieli rządów państw zrzeszonych w EWG był gen. Charles de Gaulle. Ale dopiero w 1975 roku w obliczu kryzysu politycznego państw Wspólnoty, konsultacje „rządowe” stały się obowiązujące dla kontynuowania integracji. Ranga tych instytucji wzrosła, gdy w 1965 roku doszło do połączenia organów Wspólnoty ${ }^{14}$. Trzeba też nadmienić, że przypisywana gen. Ch. de Gaulle'owi koncepcja federacyjna, tzw. „Europa ojczyzn”15 (określenie to nie jest jego autorstwa), przedstawiała go jako wielkiego zwolennika tej idei, niezależności ekonomicznej i militarnej Francji, a także innych ,państw narodowych”.

\footnotetext{
${ }^{12}$ L.W. Zyblikiewicz, Narody i..., w: E. Cziomer, L.W. Zyblikiewicz, dz. cyt., s. 70.

${ }^{13}$ J. Regulski, Samorzad III Rzeczypospolitej, Koncepcje i realizacja, Warszawa 2000, s. 367.

${ }^{14}$ D. Dziewulak, Systemy szkolne Unii Europejskiej, Warszawa 1997, s. 19.

${ }^{15}$ F. Emmert, M. Morawiecki, dz. cyt., s. 19.
} 
Pierwotnie EWG eksponowała zadania wewnętrznej integracji gospodarczej ${ }^{16}$, dążąc do utworzenia wielkiego rynku wydobywczego i metalurgicznego, który mógłby konkurować nie tylko z Japonią, USA, ale także z ówczesnym rynkiem Europy Środkowo-Wschodniej. Zgodnie z art. 2 Traktatu rzymskiego głównym zamysłem EWG było „przyczynienie się do harmonijnego rozwoju życia gospodarczego we Wspólnocie, stałego i zrównoważonego wzrostu gospodarczego, większej stabilności, szybszego wzrostu stopy życiowej i ściślejszych związków między państwami członkowskimi" ${ }^{17}$. Jak się okazało, dobrobyt ekonomiczny społeczeństw zachodnich - choć nie powszechnie i równomiernie (,wyspy” materialnego ubóstwa) - w znacznej mierze korelował dotychczas z powyższą deklaracją. $Z$ tej m.in. przyczyny, wzorując się na doświadczeniach związanych z działalnością EWWiS, EWG i EWEA, 7 lutego 1992 roku podpisano Traktat z Maastricht ${ }^{18}$ i 1 listopada 1993 roku utworzono Unię Europejską ${ }^{19}$. Chociaż posłużono się tu terminem „Unia Europejska”, to jednak „struktura prawno-instytucjonalna UE została przejęta od Wspólnot”20. Dlatego A. S. Bidwell używa zamiennie określenia „Wspólnoty Europejskie”. Obecnie w Europie i świecie ${ }^{21}$ występują dwa główne modele integracyjne: 1. „Model europejski”, w którym obszar autonomii państwowej i gospodarczej ,jest ograniczony lub nawet wyeliminowany" (UE) i 2. „Model amerykański” dający państwom członkowskim „spory margines autonomii nawet $\mathrm{w}$ sferach objętych integracją"22. Wiadome jest, że koncepcje integracyjnej „wizji” Europy nadal ewoluują (propozycje gospodarcze W. Brytanii i innych państw z 2005 r. itp.).

Oprócz integrowania ponadnarodowych organizacji gospodarczych, również organizacje oświatowe w Europie należą do sieci skomplikowanego, skonsolidowanego wokół swych celów systemu instytucji międzynarodowych. Ich działalność prowadzi się coraz intensywniej w duchu zawierającym kontrowersyjne ,przeświadczenie, iż wiele problemów współczesnych nie może być badanych w kategoriach państw narodowych i stosunków międzypaństwowych, lecz jedynie w kategoriach procesów globalnych" ${ }^{23}$. Zbyt deterministyczne przeświadczenie autorów powyższej idei, nie pozwala im dostrzec innej, spośród istniejących, alternatywy i powoduje, że integra-

${ }^{16}$ W. Rabczuk, Polityka edukacyjna Unii Europejskiej na tle przemian w szkolnictwie krajów czlonkowskich, Warszawa 1994, s. 78.

${ }^{17}$ K. Michałowska-Gorywoda, Geneza, cele i..., w: Unia Europejska.., s. 19.

${ }^{18}$ C. Mik, dz. cyt., s. 61.

${ }^{19}$ K. Michałowska-Gorywoda, Geneza, cele i..., w: Unia Europejska..., s. 9.

${ }^{20}$ A. S. Bidwell, Unia Europejska a państwa członkowskie, Wspótpraca na co dzień, Wrocław 1999, s. 9.

${ }^{21}$ Poza: CEFTA, EFTA, NAFTA, APEC, patrz w: Z. Wysokińska, J. Witkowska, Integracja europejska, Warszawa-Łódź 2000, s. 310-313; F. Emmert, M. Morawiecki, dz. cyt., s. 16; C. Mik, dz. cyt., s. 4; E. Cziomer, Bezpieczeństwo międzynarodowe, w: E. Cziomer, L.W. Zyblikiewicz, dz. cyt., s. 149.

${ }^{22}$ C. Mik, dz. cyt., s. 3.

${ }^{23}$ L. W. Zyblikiewicz, Struktura i funkcjonowanie wspótczesnej gospodarki światowej, w: E. Cziomer, L. W. Zyblikiewicz, dz. cyt., s. 185. 
cja europejska w wielu aspektach dokonuje się „bez granic”24. Zjawisko to dotyczy także zróżnicowanych organizacji oświatowych.

Europejskie organizacje oświatowe dzielą się na „pozarządowe” i ,międzyrządowe"25. Najbardziej bodaj uniwersalnym typem organizacji łączącym poszczególne kraje jest Organizacja Narodów Zjednoczonych ${ }^{26}$. Kraje te, głównie Republika Federalna Niemiec, mają znaczny udział w finansowaniu ONZ i jej agend. Natomiast UE jest federacją gospodarcza, choć wpływa na wiele innych dziedzin międzynarodowych, w tym oświatowych, poprzez swoje agendy. Pośród 11 agend unijnych dwie mają charakter szkoleniowo-edukacyjny: Europejskie Centrum Rozwoju Szkolenia Zawodowego (założone w 1975 r.) i Europejska Fundacja Szkoleniowa (założona w 1990 r.).

Oprócz wymienionych instytucji (agend edukacji zawodowej), pomocny dla dalszej synchronizacji lub integracji korporacyjnej Europy ma być postulowany ideał wychowania $^{27}$ i projekt idealistycznego ,wspólnotowego modelu szkoły”28. W związku z tym ustawicznie reformowanym systemom edukacyjnym przypisuje się coraz większe znaczenie, w procesie konsekwentnej implementacji idei „zjednoczonej Europy” do świadomości narodów, poprzez obiecywany wzrost zamożności, wymianę kulturalną, a szczególnie stopniową integrację edukacji. Mimo odwoływania się UE do niezależności każdego państwa, cele strategii integracyjnej dotyczą bardzo trudnego kulturowo i społecznie procesu poszukiwań, w jakimś stopniu skonsolidowanego strukturalnie, programowo, europejskiego systemu dydaktycznego. I. Kość definiuje go następująco: „Europeizację oświaty można zatem uznać za proces, którego efektem będzie zbliżenie do siebie odmiennych systemów edukacyjnych ( $\mathrm{w}$ tym również systemów kształcenia nauczycieli pod względem ich struktury, treści, metod i celów)"229. Dlatego zrozumiała wydaje się też nieufność państw z powodu sugerowania częściowego lub daleko idącego zrzeczenia się przez nie suwerenności, w imię racji gospodarczo-ekonomicznych i edukacyjnych, co w praktyce oznacza istotny zakres uzależnienia również o charakterze politycznym ${ }^{30}$. Można wprawdzie zgodzić się na sugestię, iż istnieje ,potrzeba otwarcia na to, co zewnętrzne i wartościowe, a jednocześnie zachowania dobrych tradycji”’31. Ale trzeba przewidywać, iż podobnie jak integracja polityczna, proces integracji oświatowej nie jest w pełni możliwy do zrealizowania z powodu przywiązania poszczególnych narodów do potrzeby samostanowienia, od-

${ }^{24}$ C. Mik, dz. cyt., s. 1.

${ }^{25}$ Tabela 5.1., zob. L.W. Zyblikiewicz, Organizacje międzynarodowe, w: E. Cziomer, L.W. Zyblikiewicz, dz. cyt., s. 65; rysunek 5.1., tamże, w: E. Cziomer, L.W. Zyblikiewicz, dz. cyt., s. 65.

${ }^{26}$ Rysunek 5.2., tamże, w: E. Cziomer, L.W. Zyblikiewicz, dz. cyt., s. 72, 70.

${ }^{27}$ D. Dziewulak, Polityka oświatowa..., s. 99-100.

${ }^{28}$ Tenże, Systemy szkolne..., s. 5.

${ }^{29}$ I. Kość, Europeizacja polskiej oświaty a kształcenie do pracy socjalnej, w: SpołeczeństwoDemokracja-Edukacja, Nowe wyzwania w pracy socjalnej, red. K. Marzec-Holka, Bydgoszcz 2000, s. 268.

${ }^{30}$ C. Mik, dz. cyt., s. $74-82$.

${ }^{31}$ R. Ossowski, Szanse i bariery integracji Polski z Europq, w: Szkoła i nauczyciel a integracja Europy, red. R. Gerlach, E. Podoska-Filipowicz, Bydgoszcz 1993, s. 32. 
rębnych, kulturowych tradycji, również tradycji oświatowych i sposobów rozumienia wartości ${ }^{32}$. Tym bardziej, że owe odrębności wyrażane wprost ${ }^{33}$ występują coraz częściej przy okazji ujawniania się sporów światopoglądowych, także etnicznych i religijnych (problem przyjęcia Turcji do UE, islam we Francji, W. Brytanii i Niemczech).

Powracając do znaczenia procesów oświatowych w kontekście problematyki integracyjnej, zawartej w poszczególnych traktatach, na początku powojennych działań integracyjnych w Europie zapowiadanych w Traktatach rzymskich, „kwestie szkolnictwa pojawiały się [...] na marginesie innych spraw" ${ }^{34}$ ekonomicznych, politycznych i realizacji praw człowieka. Tak więc Traktat rzymski (z 1957 r.) nie interpretował zasadniczo roli państw europejskich wobec oświaty. Mimo to art. 118 oraz 128 Traktatu przewidywał najpierw ścisłą koordynację ,kształcenia i doskonalenia zawodowego" ${ }^{35}$. Stąd formułowano wiele dokumentów podejmujących wspólne inicjatywy oświatowe. Jedną z nich okazała się „koncepcja międzynarodowej ustawy edukacyjnej" ${ }^{36} \mathrm{i}$ nie stanowi ona ostatniej inicjatywy w tym względzie.

Aby zabezpieczyć podstawowe dobra ludzkie, w tym prawo do oświaty, opracowano dokumenty mające ugruntować i chronić podstawowe prawa człowieka w dziedzinie podstawowych wolności i praw, także praw, jak wspomniałem, oświatowych. Są to następujące dokumenty międzynarodowe o charakterze powszechnym: „Powszechna Deklaracja Praw Człowieka” (Paryż, 10 grudnia 1948 r.), Artykuł 26, pkt.1 $2,3^{37}$, „Konwencja w sprawie Zwalczania Dyskryminacji w Dziedzinie Oświaty" (Paryż, 15 grudnia 1960 r.; Dziennik Ustaw 1964 r., Nr 40, poz. 268): Preambuła oraz Artykuły 1-5, „Międzynarodowy Pakt Praw Gospodarczych, Społecznych i Kulturalnych" (Nowy Jork, 16 grudnia 1966 r.; Dz. U. 1977 r., Nr 38, poz. 169): Część III, Art. 13, pkt 1, 2: a, b, c, d, e, 3, 4, „Protokół Nr 1 Do Konwencji o Ochronie Praw Człowieka i Podstawowych Wolności" (Paryż, 20 marca 1952 r.; Dz. U. 1995 r., Nr 36, poz. 175, zmiany: Dz. U. 1998 r., Nr 147, poz. 962): Art. $2^{38}$.

W sprawie ochrony prawa do oświaty, edukacji i wychowania, deklaracje składały poniższe instytucje europejskie:

\section{- Rada Europy}

„Pierwszą" powojenną instytucją o charakterze wyraźnie gospodarczym, a także politycznym, społecznym, kulturalnym, prawnym i oświatowym, dążącą do integracji i współpracy na ww. płaszczyznach została Rada Europy (Conseil de l’Europe - CE).

${ }^{32}$ J. Jacobs, Wartości, naturalizm i nauczanie o wartościach, Edukacja Filozoficzna 1995, vol. 19, s. $179-188$.

${ }^{33}$ Obawy Wielkiej Brytanii przed nadawaniem Unii Europejskiej większych kompetencji w dziedzinie szkolnictwa niż tych, które są przynależne władzy państwowej danego kraju, w tym przypadku chodzi o kompetencje Wielkiej Brytanii, patrz: W. Rabczuk, Polityka edukacyjna..., s. 72-73.

${ }^{34}$ Tamże, s. 72.

${ }^{35}$ D. Dziewulak, Systemy szkolne..., s. 20.

${ }^{36}$ A. Smołalski, Koncepcja międzynarodowej ustawy edukacyjnej (fragmenty), w: Szkoła i nauczyciel a integracja Europy..., s. 275.

${ }^{37}$ Prawo wyznaniowe. Wybór źródet, red. K. Warchałowski, Warszawa 2000, s. 31.

${ }^{38}$ Tamże, s. 64. 
Rada Europy nie jest Radą Europejskąa ${ }^{39}$ Rada Europejska została założona 5 maja 1949 roku przez 10 państw i obrała za swą siedzibę Strasburg (Francja Zachodnia Alzacja). Obecnie należą do niej wszystkie kraje UE, w tym Polska.

Rada Europy realizuje, oprócz wymienionych celów, przede wszystkim priorytety ekonomiczne. Ma jednak istotny finansowy i programowy wpływ na europejskie zadania oświatowe. Bardziej bezpośredni wpływ na nie posiada wydzielona z Rady Europy - Rada Współpracy Kulturalnej (Conseil de la Coopération Culturelle - CDCC), której powierzono analizę zagadnień oświatowych w Europie i innych państwach świata. W latach 90., po przeprowadzeniu analizy rozwoju oświaty na poziomie organizacji i nauczania początkowego w Europie Zachodniej, najważniejszymi zakresami ogólnymi działań Rady Współpracy Kulturalnej (CDCC) stały się także: „europejskie obywatelstwo a tożsamość kulturowa, oświata i kultura w społeczeństwie okresu przemian, kultura i oświata dnia codziennego" ${ }^{\prime 40}$. Działania te dotyczyły modelu kształcenia ucznia i nauczyciela, analizy celów i treści kształcenia poszczególnych przedmiotów i planów nauczania, oraz najczęściej występujących problemów nauczania „w zakresie szkoły początkowej”41.

\section{- UNESCO}

Największą świecką organizacją międzynarodową zajmującą się także problematyką edukacyjną i wychowawczą w Europie i w świecie jest Organizacja Narodów Zjednoczonych ds. Oświaty, Nauki i Kultury, tj. United Nations Educational Scientific and Cultural Organization - UNESCO ${ }^{42}$. Utworzyły ją 44 państwa, w tym Polska (16 listopada 1945 r.), na międzynarodowej konferencji w Londynie na podstawie tzw. „Aktu Konstytucyjnego”. Dokument ten uzyskał moc prawną 4 listopada $1946 \mathrm{roku}^{43}$.

UNESCO jest Organizacją Narodów Zjednoczonych do spraw Oświaty, Nauki i Kultury, zrzeszającą 186 państw członkowskich (w 1984 r. - bez USA), z siedzibą w Paryżu. Powstała na wzór Międzynarodowego Instytutu Współpracy Intelektualnej Ligi Narodów, zbierając i opracowując dane „o zagranicznych systemach oświato-

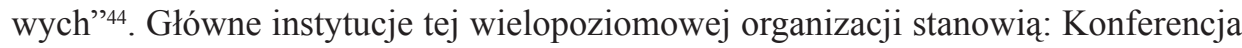
Generalna, Rada Wykonawcza, Sekretariat (problematyka oświatowa i kulturalna, nauki społeczne i komunikacja). Propaguje ona idee oświeceniowego i liberalnego humanizmu. Mimo iż przeżywała w swej historii wewnętrzne kryzysy i rozłamy (lata 1952-1954, wystapienie Węgier, Polski i Czechosłowacji; 1984-1985 wystąpienie Wielkiej Brytanii i USA), nadal utrzymuje się ze składek państw członkowskich,

${ }^{39}$ F. Emmert, M. Morawiecki, dz. cyt., s. 78.

${ }^{40}$ D. Dziewulak, Systemy szkolne..., s. 31; R. Pachociński, Zmiany w dydaktyce szkoty zachodniej, Społeczeństwo Otwarte 1996, nr 9, s. 35-40.

${ }^{41}$ D. Dziewulak, Systemy szkolne..., s. 31.

${ }^{42}$ K. Żygulski, UNESCO, w: Encyklopedia pedagogiczna, red. W. Pomykało, Warszawa 1993, s. $880-882$.

${ }^{43}$ L.W. Zyblikiewicz, Narody i..., w: E. Cziomer, L.W. Zyblikiewicz, dz. cyt., s. 76.

${ }^{44}$ A. Mońka-Stanikowa, Szkoła średnia w krajach zachodnich, Warszawa 1976, s. 17. 
dotacji ONZ, a także około 500 pozarządowych, międzynarodowych organizacji, federacji, związków i stowarzyszeń, mających decydujący wpływ na jej cele i wydatki. Część tych związków i stowarzyszeń, otrzymuje zwrotnie od UNESCO około $40 \%$ subsydiów na działalność kulturalną: film, teatr, sztuki plastyczne, muzykę oraz masową komunikację, tj. o 20\% więcej niż UNESCO wydaje na działalność ściśle edukacyjną. Zatem w latach 80. roczny budżet UNESCO wynosił 175 milionów dolarów, z czego na zadania oświatowe wydawano około $20 \%$. W ostatnim czasie wiele środków przeznaczało się na cele komunikacji globalnej, tj. wdrażanie technik komunikacji zbiorowej: radiowo-telewizyjnej, komputerowej i innych technik wizualizacji informacji. Liczne są też afiliowane z UNESCO organizacje prooświatowe: związkowe, naukowe, religijne, np.: Światowa Federacja Związków Nauczycieli (FISE), Międzynarodowa Federacja Wspólnot Wychowawczych (FICE), Światowa Organizacja Wychowania Przedszkolnego (OMEP), Międzynarodowa Organizacja Nauczania Katolickiego (OIEC), Komitet Międzynarodowego Centrum Katolickiego (C.C.I.C) i inne ${ }^{45}$. Polski Komitet ds. UNESCO ma swoją siedzibę w Warszawie.

\section{- UNICEF}

UNICEF $^{46}$ czyli Unitend Nations Children's Found jest Funduszem Narodów Zjednoczonych działającym w ramach międzynarodowej struktury ONZ. Zajmuje się działalnością na rzecz wyżywienia dzieci, ochrony ich zdrowia i oświaty. Powstał 11 grudnia 1946 roku uchwałą Zgromadzenia Ogólnego Narodów Zjednoczonych (wówczas Międzynarodowego Funduszu Narodów Zjednoczonych). Z inicjatywą założycielską UNICEF-u wystapił działacz z Polski dr Ludwik Reichman. W 1953 roku włączenie UNICEF-u na stałe w system ONZ pozwoliło intensyfikować globalną aktywność wyżywieniową, medyczno-lekarską i oświatową. Dlatego oprócz Europy rozpoczęto działania na obszarze krajów Trzeciego Świata (Afryki, Azji, Ameryki Południowej) i Europy Środkowo-Wschodniej. Podobnie jak w przypadku UNESCO, fundusze UNICEF-u składają się z wpłat poszczególnych rządów, międzynarodowych organizacji, agencji, innych instytucji i osób prywatnych oraz organizacji pozarządowych. Organem kierowniczym jest „Rada Zarządzająca” i „Sekretariat” z główną siedzibą (sekretariatu) w Nowym Jorku. Natomiast Polski Komitet UNICEF-u utworzono w Warszawie.

\section{- EFA}

EFA jest Międzynarodowym Forum Konsultacyjnym na rzecz Edukacji dla Wszystkich - „Education for All”, założonym w Paryżu, w 1991 roku. W ramach EFA współpracują ministrowie edukacji poszczególnych państw, przedstawiciele krajów rozwijających się, instytucje międzynarodowe i bilateralne, organizacje pozarządowe i fundacje,

45 Jan Paweł II, Nauczanie Papieskie, Rok 1982, red. E. Weron, A. Jaroch, Poznań 1993, cz. 5, nr 1, s. 802.

${ }^{46}$ W. Pomykało, UNICEF, w: Encyklopedia pedagogiczna..., s. 883-884. 
w celu upowszechnienia edukacji na poziomie podstawowym (elementarnym, początkowym).

Zatwierdzany plan pracy Forum EFA realizowany jest przez jego Sekretariat. Sekretariat ten ma siedzibę w UNESCO, w Paryżu. W latach 1995-1996 poszczególne działania Forum EFA finansowały: Dania, Finlandia, Włochy, Norwegia, Holandia, Szwecja, Bank Światowy, agendy ONZ: UNFPA, UNDP, UNESCO, UNICEF.

Ponadto EFA współpracuje ze Światowym Stowarzyszeniem Prasowym w celach promocji swoich działań oświatowych i ideowych, a Sekretariat Forum publikuje biuletyn „EFA 2000” w pięciu językach, raporty edukacyjne pt. „Education pour tous: situation et tendances” („Edukacja dla wszystkich: sytuacja i tendencje”) oraz inne broszury i dokumenty.

\section{- OCDE: Komitet Edukacyjny i CERI}

OCDE, tj. Organisation pour la Coopération et le Développement Économique, powstała w 1960 roku w Paryżu i jest przede wszystkim organizacją gospodarczo-ekonomiczną, w skład której wchodziło 36 państw (m.in. USA i Japonia), w tym 12 krajów UE. Wymieniona wyżej Organizacja Współpracy i Rozwoju Ekonomicznego (OCDE) wywiera oczywisty wpływ na edukację dzięki dotowaniu tej działalności. Nadto posiada w swoich strukturach wydzielony Komitet Edukacyjny i CERI. Komitet Edukacyjny wyznacza główne kierunki polityki oświatowej w Europie i świecie, natomiast CERI („Centrum Badań i Innowacji Oświatowych”) realizuje badania pedagogiczno-oświatowe. Działalność oświatową Komitetu i badania CERI finansuje OCDE jak również fundacje państwowe i prywatne.

OCDE projektuje perspektywiczne kierunki rozwoju szkolnictwa, przeprowadza analizy oceniające systemy oświatowe poszczególnych państw, przewiduje rozwój oświaty w kontekście przewidywanych potrzeb gospodarczych, ekonomicznych i technologicznych. Promuje także program „nowych technologii informacyjnych" ${ }^{4}$, dla wdrażania nauczania permanentnego w obecnym i nadchodzącym stuleciu (od 2001 roku). Wyniki swych badań OCDE przedstawia w raportach pokonferencyjnych dotyczących problematyki edukacyjnej ${ }^{48}$.

\section{- UNESCO - BIE}

W 1969 roku włączono do UNESCO „Międzynarodowe Biuro Oświaty” - BIE. Ma ono siedzibę w Genewie i oprócz innych instytucji zajmuje się jednocześnie globalnymi problemami oświatowymi w kontekście porównawczym. Wymiana poglądów i wniosków w tym zakresie dokonuje się na tzw. sesjach „Międzynarodowych Konferencji Oświatowych", na które przybywają ministrowie oświaty poszczególnych państw wchodzących w skład BIE. Informują oni BIE o stanie i specyfice szkolnictwa swego państwa. Mogą też zgłaszać własne postulaty.

${ }^{47}$ D. Dziewulak, Systemy szkolne..., s. 32.

${ }^{48}$ A. Mońka-Stanikowa, dz. cyt., s. 44. 
UNESCO - BIE sygnalizuje wiele aspektów działalności oświatowej, opracowując konkretne raporty (np. raport „E. Faure'a”). Dotyczą one: działań planistyczno-oświatowych, nadzoru szkolnego, kierowania systemami placówek wszystkich szczebli, finansowania edukacji, orientacji zawodowej, przygotowywania aktualnych programów nauczania, a także ,doskonalenia dydaktyki poszczególnych przedmiotów, alfabetyzacji dorosłych i badań oświatowych"49. Dążąc do pełniejszej integracji państw UE i państw Europy Środkowo-Wschodniej, UNESCO - BIE wdraża „europejski program rozwoju oświaty" polegający na pokojowej koegzystencji i przestrzeganiu praw człowieka, upowszechnieniu edukacji permanentnej, kształceniu nauczycieli, znajomości języków obcych zwłaszcza przez młodzież szkół średnich i wyższych, oraz „wzajemnym uznaniu dyplomów studiów wyższych" ${ }^{50}$. Ma to istotne znaczenie dla przemieszczania się wysoko kwalifikowanych kadr naukowych, szczególnie z Europy Środkowo-Wschodniej do Europy Zachodniej.

Pomimo różnic występujących w systemach edukacyjnych państw biorących udział w europejskich i globalnych działaniach na rzecz oświaty, kultury i nauki, zmierzają one ideowo w jednym kierunku. Zarówno cele UE, Rady Europy, OCDE, UNESCO, pozostałych organizacji afiliowanych przy tych organizacjach, także działania UNESCO - BIE dotyczą aktualnych faktów oświatowych, przedstawianych w szerokiej perspektywie geograficzno-kulturowej. Natomiast poza współpracą polityczną pewnym wyjaśnieniem jest to, iż aktywność owych międzynarodowych i ponadnarodowych instytucji finansują te same podmioty, wymienione poprzednio, a które umożliwiają prowadzenie tak olbrzymich przedsięwzięć. Przez działania ogólnoświatowe UNESCO - BIE, także owe instytucje wpływają na edukację europejską. Dążą - jak twierdzą - do ukształtowania „obywatela Europy” ${ }^{\text {1 }}$, tj. „Europejczyka świadomego własnych narodowych korzeni, kierującego się ideą respektowania praw człowieka", w integrowanej ekonomicznie, etnicznie i kulturowo „Europie szkolnej”52. Jednak poczucie rzeczywistego przedkładania „europejskości” nad chrześcijańską tożsamość narodową, wynikającego z głoszonego usilnie postulatu „wejścia do Europy”, umniejszają znaczenie tych państw, które z pewnością budowały jej religijno-kulturowe fundamenty i jest odczytywane jako próba wykluczenia ich historycznych dokonań i ograniczenia znaczenia kulturowej podmiotowości.

Aby umacniać kulturowe fundamenty przeszłości i współczesności, w Europie Zachodniej powstały również katolickie, prooświatowe instytucje edukacyjne i wychowawcze o zasięgu europejskim i światowym: Światowa Unia Nauczycieli Katolickich - UMEC ${ }^{53}$, Międzynarodowe Biuro Nauczania Katolickiego - OIEC, Europejski Komitet Szkolnictwa Katolickego - CEEC (Comité Européen pour L'Enseignement Ca-

${ }^{49}$ D. Dziewulak, Systemy szkolne..., s. 33.

${ }^{50}$ Tamże, s. 34.

${ }^{51}$ B. Bartz, Europa obywateli i niektóre przedsięwzięcia gospodarczo-oświatowe na rzecz jej rozwoju, Kwartalnik Pedagogiczny 1989, nr 4, s. 133.

${ }^{52}$ D. Dziewulak, Systemy szkolne..., s. 35.

${ }^{53}$ Organizacja powstała w październiku 1951 roku w Rzymie, w: Catholicisme hier, aujourd' hui, demain, Encyclopédie, t. 4e, red. G. Jacquemet, Paris 1987, s. 214. 
tholique, Bruxelles), Watykańska Kongregacja do spraw Wychowania Katolickiego. W odpowiednim zakresie edukacji i wychowaniu służą: Zgromadzenie Ogólne Rady Konferencji Biskupich Europy - CCEE („RADA” składa się z około 34 krajowych Episkopatów Europy ${ }^{54}$ ), Katolickie Biuro Informacji i Inicjatyw Europejskich, Centralny Urząd Statystyki Kościoła.

Podstawowymi dokumentami dla nauczania i wychowania katolickiego, we wszystkich instytucjach szkolnych tego typu w Europie i na świecie, którymi się one kierują są: Deklaracja o wychowaniu chrześcijańskim - Gravissimum educationis, Konstytucja duszpasterska o Kościele w świecie współczesnym - Gaudium et spes, dokument Kongregacji do spraw Wychowania Katolickiego - Szkoła Katolicka: „La Scuola catholica”, instrukcja - Ecclesiae imago, Kodeks Prawa Kanonicznego, Statut Szkoły Katolickiej. Jak wspomniano podstawowym i najważniejszym dokumentem Soboru Watykańskiego II dotyczącym wychowania katolickiego, jest soborowa Deklaracja o wychowaniu chrześcijańskim Gravissimum educationis ${ }^{55}$. Dokument ten przed przekazaniem do realizacji został zatwierdzony przez papieża Pawła VI i Ojców Soboru Watykańskiego II - 28 października 1965 roku.

Wcześniejszym od deklaracji Gravissimum educationis dokumentem jest encyklika „O chrześcijańskim wychowaniu młodzieży” papieża Piusa XI z dnia 31 grudnia 1929 roku. Na szczególną uwagę zasługują dokumenty Watykańskiej Kongregacji do spraw Wychowania Katolickiego - „La Scuola catholica”, tj. Szkoła Katolicka z dnia 19 marca 1977 roku, „Katolik świecki świadkiem wiary w szkole” z dnia 15 października 1982 roku - „Il laico catholica testimone della fede nelle scuola”, „Wskazówki wychowawcze na temat miłości ludzkiej. Założenia wychowania seksualnego" z dnia 1 listopada 1983 roku - „Orientamenti educativi sull'amore umano. Lineamenti di educazione sessuale" i Adhortacja apostolska Jana Pawła II - Catechesi tradendae. Instytucje edukacyjno-wychowawcze mające uznanie władz kościelnych kierują się tymi dokumentami adekwatnie do swych zadań.

Biorąc pod uwagę formalno-prawne kryterium „,uznania” przez władze kościelne erygowanych organizacji, można wyróżnić organizacje: publiczne, założone przez władze kościelne (KPK, kan. 299, § 1), prywatne, posiadające uznanie władz kościelnych (KPK, kan. 299 § 1) i inne stowarzyszenia prywatne, związane w pewnym tylko stopniu z działalnością Kościoła, nieubiegające się jednak o uznanie władz kościelnych ${ }^{56}$.

Nauczycielami i edukacją zajmuje się uznany przez Kościół rzymskokatolicki Światowy Związek Nauczycieli Katolickich - UMEC (Union Mondiale des Enseignants Catholiques). Inna uznana organizacja o zasięgu światowym, posiadająca siedzibę w Europie, to wspomniane Międzynarodowe Biuro Nauczania Katolickiego - OIEC (Office International de l'Enseignement Catholique, Bruksela), bardzo ak-

${ }^{54}$ PS, KAI, Nasz Dziennik 2000, nr 246, s. 6.

${ }^{55}$ Sobór Watykański II. Konstytucje. Dekrety. Deklaracje, Kraków 1967, s. 9.

${ }^{56}$ J. Krukowski, Prawo chrześcijan do stowarzyszania się i możliwości jego realizacji w prawie kanonicznym i polskim, w: Kościót i Prawo, t. 9, red. J. Krukowski, F. Mazur, F. Lempa, Lublin 1991, s. 196. 
tywne, działające, jak wskazał Jan Paweł II, na rzecz „edukacji w duchu Ewangelii” ${ }^{57}$. Ta międzynarodowa instytucja współpracuje z agendami ONZ i UE, mając przy nich stałych przedstawicieli. $\mathrm{W}$ ramach corocznych, $\mathrm{z}$ reguły międzynarodowych, kongresów $^{58}$ dokonuje bilansu polityki edukacyjnej i stopnia zharmonizowania nauczania w szkołach katolickich całego świata, poddaje systematycznej ocenie współpracę szkół katolickich i katolickich organizacji z danymi władzami lokalnymi, rządami krajów i organizacjami międzynarodowymi, świeckimi i religijnymi, np. UNESCO, UNICEF, FAO, SOPEC, NCEA, UMEC, CEEC i in. Każdego roku określa, modyfikuje i koreluje najważniejsze zadania edukacyjne, wychowawcze, charytatywne. W miarę posiadanych możliwości powołuje mecenat stypendialny dla uczniów i studentów z państw szczególnie zagrożonych ubóstwem i analfabetyzmem na różnych kontynentach. OIEC realizowała swe programy edukacyjno-charytatywne m.in. w Hondurasie, Nikaragui, Burundi i w Polsce. Finansowała stypendia edukacyjne dla dzieci bezdomnych, porzuconych, sierot, sierot wojennych, uczniów wypisanych ze szkół katolickich z powodu trudności finansowych ich rodzin poszkodowanych przez biedę i klęski żywiołowe.

Pomimo działalności charytatywnej instytucja ta jest przede wszystkim szeroko rozumianym ,instrumentem edukacji katolickiej”. Fenomen jej polega nie tylko na rozbudowanych strukturach i globalnym oddziaływaniu, ale także na finansach. Ponieważ nie może konkurować $\mathrm{z}$ donatorami i zasobami finansowymi agend oświatowych ONZ-tu, aktywa OIEC-u, np. w 1998 roku, aż w 56\% składały się z darowizn, a mimo to organizacja nadal podejmuje działania znacznie wykraczające poza cele edukacyjne. Edukacyjno-religijny motyw tej „służby” jest przy tym jedną z najbardziej charakterystycznych cech katolickiej działalności prooświatowej reprezentowanej przez tę organizację. Powyższa charakterystyka tej największej organizacji katolickiej, zajmującej się szkolnictwem pokazuje, jak bardzo przywiązuje ona wagę do wspierania działalności oświatowej i zintegrowanej z nią funkcji ewangelizacyjnej ${ }^{59}$. Tak zintegrowana katolicka działalność oświatowa musi kształtować „pełną osobowość” ucznia, świadczyć światu realną o nim samym prawdę, otwierać się na kultury i narody, ekumenizm i uniwersalność. „W trudnych czasach” powinna cechować ją odwaga oraz wielkoduszność wychowawcza w realizacji teologicznego i teocentrycznego „modelu wychowawczego" ${ }^{\circ 0}$ dla lepszej predykcji zagadnień oświatowych obecnie i w przyszłości.

${ }^{57}$ Éduquez les jeunes jusqu' à leur maturité humaine et chrétienne. Discours au Congrès mondial de l'Office international de l'Enseignement catholique, w: La Documentation Catholique 1994, Sommaire Du Numero 2092, s. 354.

${ }^{58}$ W Jajpur (Indie, 18-21kwietnia 1998 r.), Krakowie (Polska, 12-15 lutego 1999 r.), Hoeven (Holandia, 1-6 sierpnia 1999 r.).

${ }^{59}$ Patrz: Deklaracja o wychowaniu chrześcijańskim „Gravissimum educationis”, w: Sobór Watykański II. Konstytucje. Dekrety. Deklaracje.

${ }^{60}$ Przemówienie bpa Cesare Nosiglia na 72 Radzie OIEC, Światowego Kongresu OIEC w Krakowie, 12-15 lutego 1999 roku. 


\section{Unification Processes in Europe and their Educational Consequences} European Educational Agenda

(Summary)

The paper presents the genesis and evolution of events connected with the creation of the European Union. This context functions as the background for the presentation of approaches and major issues related to establishing and agreeing on the legal bases of functioning for European pro-educational institutions (public and religious, esp. Catholic), documents and educational frameworks, achievements and ways of conduct in the period determined by the requirements of the Present. 